\title{
Grounding a Theory of Firms in the Natural Sciences
}

\author{
Shann Turnbull ${ }^{1}$
}

Received: 23 May 2016 / Accepted: 24 November 2016 / Published online: 23 January 2017

(C) Springer International Publishing 2017

\begin{abstract}
This paper grounds the theory of any type of firm in the science of control and communication described as cybernetics. It is also grounded in the physiological and neurological limitations of humans to receive, store, process and act upon data to coordinate their activities. To overcome limitations in the market failure theory of the firm identified by leading scholars, Transaction Byte Analysis (TBA) is introduced. TBA is based on economising bytes rather than costs and is applicable to all types of organisations of any specie. TBA is shown to subsume Transaction Cost Economics and explain why firms exist as hierarchies or in other forms. Inconsistent and contrary behaviour in humans are recognised. Cybernetic laws show how to minimise these problems and allow people with limited ability to transact bytes to improve their ability and reliability to manage complexity in social institutions. TBA is used to provide answers to questions raised by Zingales in his search for "new foundations" to explain how different types firms arise in the new economy.
\end{abstract}

Keywords Cybernetics $\cdot$ Self-regulation $\cdot$ Tensegrity $\cdot$ Theory of firms $\cdot$ Transaction cost economics

\section{Introduction}

The purpose of this paper is to show how the natural sciences can explain why firms of any type exist and explain aspects as to how they are organised as hierarchies, teams or networks in the new economy. The analysis takes into account the physiological and neurological limitations of individuals to receive store, retrieve, manipulate, use or transmit data.

Any cooperative activity within and/or between any specie requires the communication of data. However, the operations of any firm, organisation or social institution, is limited by the ability of the individuals involved to process data. This creates an imperative for humans to be organised within a firm so as to minimise data overload and errors. The economising of data provides an alternative to

Shann Turnbull

sturnbull@mba1963.hbs.edu

1 International Institute for Self-governance, PO Box 266, Woollahra, Sydney 1350, Australia 
economising costs as a basis to consider why hierarchical firms exist and explain other types that have emerged.

Unlike costs, data represents physical states of matter or energy. Data represents changes in the state of matter and/or material that make a difference. Any such change is recognised in units called "bits" with a group of bits being described as a "byte" (Kurzweil 1999: 299). While it may not be possible to reliably quantify information, knowledge or wisdom, no changes in their state can occur without transacting bytes. Bytes provide a basis to determine the physiological and neurological capacity of individuals to transact data internally or communicate with others.

The storage and transaction of bytes introduces changes in the energy states or configuration of matter. Economising the transaction of bytes economises the energy and/or materials required by any biota to survive in novel unknowable complex environments. For this reason, the framework developed in this paper is referred to as Transaction Byte Analysis (TBA). This phrase is chosen to reflect both the similarity and the differences from theories of the firm based on Transaction Cost Economics (TCE) arising from the work of Coase (1937) and Williamson (1975).

All biota, firms or social institutions depend upon collecting and processing data to control their activities. The word "architecture" is used to describe the pattern of control and communication channels used for connecting neurons in biota or the wiring of computer chips or of computer components.

The word "architecture" in the corporate finance literature may have a different meaning as described by Smith (2001: 1). Smith uses the phrase "organizational architecture" "to refer to three key aspects of the firm: (a) the assignment of decision rights within the organization, (b) the structure of systems to evaluate the performance of both individuals and business units, and (c) the method of rewarding individuals. In this paper the word architecture includes data networks. Some data networks involved in points (a) and (b) above may be embedded in the constitution of a firm or social organisation to place them outside the power of management to re-assign. So TBA introduces a scientific basis to design the constitutions of firms or other social institutions and the architecture of how they may become connected (Turnbull 2002b; $2008 ; 2014 a, b)$. In this way the word architecture can be applied to network firms found in the new economy (Craven et al. 1996; Zingales 2000; Pirson and Turnbull 2011; Turnbull 2002a; Turnbull and Pirson 2015)

The design of the information and control architecture of neurons, computer chips, or people in a firm, determine how they operate and the capabilities of the system they make up. This paper identifies elements of design criteria found in nature to minimise information blockages, errors, biases and overloads that can arise in organisations managing complexity. The design rules are commonly utilised by engineers to design machines and devices to create self-regulating operations.

The rules of self-regulation and self-governance have been established by the science of cybernetics. Cybernetics was identified and defined by MIT mathematician Norbert Wiener (1948) as "the science of control and communication, in animal and the machine". To quote another pioneer of cybernetics, W. Ross Ashby "The truths of cybernetics are not conditional on their being derived from some other branch of science. Cybernetics has its own foundations" (Ashby 1968: 1). Ashby demonstrated that cybernetics is grounded in the logic of mathematics.

The laws of cybernetics articulated by von Neumann (1947), Shannon (1949), Ashby and others are concerned with the problems of processing data and controlling variables in man or machine. These laws reveal strategies for overcoming information over-load, errors in decision making, communications or managing many variables by adopting an appropriate architecture. 
Cybernetic laws explain the architecture of the control and communications systems found in humans and throughout nature. TBA utilises these laws to provide a basis to evaluate the capacity of firms to manage complexity reliably and so their ability to obtain competitive advantages.

Humans are complex systems and their behaviour can be variable, inconsistent and contrary. However, humans have developed ways to survive and reproduce and this can provide lessons for designing the architecture of firms and/or for developing processes for designing their architecture. Modern humans, unlike small brained ants and bees and all other specie, are the only biota that act inconsistently with the laws of nature by attempting to manage complex tasks like designing, constructing and managing their homes centrally with command and contol "authority" systems considered by Coase (1937).

Human behaviour is determined by the way they are "wired up". Both nature and nurture determine the connections established in the brain, which controls behaviour. Humans exist in an interactive cybernetic relationship with their environment (Wearing 1973). Because human psychology is variable, different individuals can respond to the same signals in different ways and the same individual may change they way they respond to the same communication at different times. In addition, both their internal and external communication and control systems are subject to errors.

Cybernetic laws explain how humans, or any other type of system, like a firm can survive when its communication and control system contains unreliable components. The strategies utilised in nature to provide assurance in the quality of communication and control for survival are also applicable to firms. In this way TBA provides a way to evaluate the integrity of a firm's governance architecture and the risk of firm survival.

The next Section considers the origin of the theory of the firm organised as a hierarchy as assumed by Coase (1937) in a market economy. It notes that the market failure theory of why firms exist was based on the assumption that hierarchies were the only alternative to markets. It ignored that hierarchies could be either public or private with different operating characteristics and that beside markets, other coordinating mechanism existed based on family/clan, associations and/or network relationships (Hollingsworth 2000). The inability of theories of the firm to either recognises or explain the operations of firms formally or informally governed by two or more control centres or boards is then discussed. Other shortcomings of the theory of the firm identified by the leading scholars in the field are then noted.

Section three considers the relevance of using bytes in the analysis of firms. The importance of data or information as a component in developing theories of the firm is reviewed. The physical process by which data is transacted within and between humans is outlined. The limited ability for humans to transact bytes is identified as determining the form of firms and the form of communication within and between firms. No firm can exist without humans transacting bytes and firms exist to manage complexity to overcome human limitations in transacting bytes.

Section four introduces cybernetic principles for overcoming unreliability in decision making, communications, or control. These principles provide a basis for obtaining as much reliability as is required by introducing a requisite variety in the relevant processes. These principles with the need to amplify regulation through supplementation provide a basis to evaluate the cybernetic integrity of a firm or for designing the architecture of firms.

Section five compares the TBA and TCE frameworks and considers the four questions raised by Zingales (2000) that need to be answered by any "new foundations" established for a theory of firms. The TBA framework is used with a case studied of a complex firm to answer the questions raised by Zingales for establishing new foundation for a theory of firms. Additional ways in which TBA grounds theory of firms in the natural sciences are also considered. However, there is room for much further work to be done. 


\section{Theory of Firms}

\section{Why Firms Exist}

Firms have existed in all types of social systems in various forms for thousands of years (BenPorath 1980; North 1985). Coase (1937) was the first to suggest why firms exist in a market economy as an authority system. Authority systems create hierarchies that dominate modern human organisations.

But as noted by Ben Porath this has not always been so and humans are the only social creatures that uses hierarchies to build and manage complex structures. Humans as huntergathers and all social creatures like ants and bees design, build and manage complex structures without markets or hierarchies but with what is described below as "Network Governance" (Pirson and Turnbull 2011; Turnbull 2000a, 2014a; Turnbull and Pirson 2015).

Coase noted that there was a cost in organising production through the market as prices of components needed to be "discovered". He stated that "This cost may be reduced but it will not be eliminated by the emergence of specialists who will sell this information". He argued that firms emerged because production could be organised under the direction of an "entrepreneur" or "employer" at less cost than discovering and negotiating prices for the supply of components. In other words firms exist because markets fail to reduce costs in organising transactions required for production. This has become known as the "market failure" reason for the existence of firms.

Coase assumed "that the supersession of the price mechanism is the distinguishing mark of the firm". However, this assumption has little relevance in primitive economies where production can be organised by kinship relationships as noted by Ben-Porath (1980) and North (1985: 558). Nor is the assumption relevant in a communist or socialist system. It may not even be relevant in a market economy when the government organises the production of some specific good or service.

Coase (1937) speculated: "Why is not all production carried on by one big firm?" He provided three answers to this question. (i) Decreasing returns to the entrepreneur from the cost of organising greater complexity; (ii) Less efficient allocation of resources, and (iii) Other advantages of small scale production such as the cost of managers in large firms increasing more than the cost of managers in small firms who value autonomy. Alchian (1950) described the problems for managers in efficiently allocating firm resources while Williamson (1975) built upon the framework created by Coase to establish what he described as Transaction Cost Economics (TCE).

Williamson (1985: 1) states that: "A transaction occurs when a good or service is transferred across a technologically separable interface". He goes on to explain that it is "an examination of the comparative costs of planning, adapting, and monitoring task completion under alternative governance structures". All these activities depend on obtaining and processing information. This supports the use of data rather than cost as the unit of analysis. There are other definitions of both a transaction and its cost, with some not involving information, as described by Klaes (2000: 567-93) who details their associated controversies.

Alchian and Demsetz (1972) presented another reason why firms exist due to what they defined as team production. They argued that: "teamwork exists when the collective output of a group of individuals is greater than the sum of the output of each of them separately, and where it is simultaneously difficult to discover each individual's contribution to the group output" (Barney and Ouchi 1986: 75). Alchian and Demsetz applied their arguments to profit sharing firms, socialist firms, corporations, mutual and non-profit firms, partnerships and 
employee unions and point out that no authoritarian control need to be involved. They explained the emergence of a hierarchy in a firm as it grows as providing a way for those with residual claims to the productivity of the teams to monitor the output of the teams that make up larger firms.

Williamson (1975) used the transaction as the basic unit of analysis for activities within the firm or through markets. The behavioural assumptions on which TCE are based are "The twin assumptions of bounded rationality and opportunism" (Williamson 1991: 8). Other types of behaviour, including trust and altruism are not included in the TCE framework (Ghoshal and Moran 1996).

Another implicit assumption of TCE is that markets, hierarchy or a hybrid system of both govern transactions. However, as noted by Ben-Porath (1980) and Ouchi (1980) families and clans can also govern transactions. Hollingsworth and Lindberg (1985: 221-2) state that there are "four distinctive forms of governance ... market, hierarchies, the clan or community and associations".

But notwithstanding the contributions of Ben-Porath (1980), Ouchi (1980), North (1985) and others, Hollingsworth et al. (1994: 5) stated 9 years later that, "Contemporary mainstream economics postulates essentially two mechanisms of governance: markets and corporate hierarchies." They go on to say, "In the limited institutional repertory envisaged by mainstream economics, corporate hierarchies are the preferred and in fact, the only 'economic', alternative to markets". Later, Hollingsworth (2000) identified two additional forms of "integrating mechanisms" - networks and government hierarchies with different characteristics to private hierarchies.

Network governance was identified as a distinguishing feature of all non-trivial stakeholder controlled firms surveyed by Bernstein (1980). Network governance has been identified as a condition precedent for self-regulation and self-governance for any organisation (Turnbull 2000c: 118). No change in the law is required to established network governed firms as is evident by the existence of The John Lewis Partnership in the UK, VISA International in the US and the Mondragon stakeholder controlled cooperatives in Spain (Turnbull 2000c: 133, 191, 207; 2002a).

The existence of six modes of governance rather than the two assumed by Coase and Williamson means that their analysis is incomplete. It does not mean that their analysis is wrong only that it needs qualifying in the same way the development of relativity theory required Newtonian mechanics to be qualified. An appropriate qualification could be that hierarchical firms exist not just because of "market failure" but also because of the failure of clan/community and associational relationships are not relevant or fail to reduce the cost of transacting outside an authority system.

Individuals working towards a common goal in a team as described by Alchian and Demsetz (1972) would be described by Hollingsworth and Lindberg (1985: 221-2) as using the "Clan/Community" or "Associative" mode of governance. So firms can exist without utilising either markets or hierarchy as described by Ben-Porath (1980) and North (1985). As noted by these authors social relationships rather than costs can be the dominant consideration for creating and maintaining a firm. There are other limitations in the current theory of the firm that are next considered.

\section{Limitations in Theories of the Firm}

The possibility of non-economic considerations creating a firm was recognised by Williamson (1975: 40) who noted that "a more satisfying trading atmosphere sometimes obtains". 
However, while citing Ben Porath a number of times, Williamson (1979; 1985: 394; 1988:71) does not appear to accept clans as a distinct alternative mode of governing transactions in the same way as Ouchi (1980: 134; 1984); Hollingsworth and Lindberg (1985: 249) and Barney and Ouchi (1986: 213, 441).

Another limitation of TCE is that it is focussed on what Coase (1937) describes as a "master/servant" or "employer/employee" relationship. Williamson (1985: 265) points out that he is "mainly preoccupied with assessing capitalist modes of organization". This does not include "non-capitalist modes" such as producer cooperatives. Williamson (1985: 265) notes the operations of those operating around the Basque town of Mondragón. In referring to other producer cooperatives Williamson asked "why is the record for producer cooperatives so weak?"

A contribution to finding an answer to this question was made by Bernstein (1980) who undertook a global survey of producer cooperatives. A common feature of all non-trivial sustainable producer cooperatives was that they possessed multiple control centres or boards as found with all the cooperatives at Mondragón (Turnbull 1995c).

Company laws in European countries mandate the establishment of two or even three boards for some firms (Analytica 1992). In Anglo countries, firms governed by more than one board, which I described as a "compound board", exist in producer cooperatives as documented by Bernstein (1980). According to Porta et al. (1999), most publicly traded firms in the world are controlled by a dominant shareholder. This creates a compound board with a component external to the firm. Around $20 \%$ of the Fortune 500 companies are in this situation (Zey and Swenson 2001). This makes compound boards the rule rather than the exception to those commonly assumed by scholars since being reported by Berle and Means (1932).

Venture capitalists commonly create a compound board through a shareholder's agreement that removes specified powers normally held by a unitary board to the venture capitalist. A division of power and decomposition of decision making labour also occurs with Leverage Buy-Outs (LBO's) when an association of investors establishes their own board to supervise the executive board. Jensen (1993: 869) noted that such arrangement provided "a proven model of governance structure" without noting that it represented a two-tiered board. Or that it decomposed decision making between operating and strategic issues in a similar manner to European two tiered boards or what Williamson (1985: 279-83) describes as M-form firms.

However, not withstanding this wide and common occurrence of compound boards they represent a phenomenon that appears to be ignored in theories of the firm. It is also a phenomenon that is ignored by scholars undertaking or using empirical research. For example, Williamson (1975: 140) noted that, "Imitation of the M-form innovation was at first rather slow" and that "prior to 1968, most European companies administered their domestic operations through U-form or holding company internal structures". However, there was less need for large European firms to adopt M-form architecture because decomposition in their decision making was an inherent feature of them possessing multiple boards as described in Analytica (1992).

The compound boards found in Europe and those created by a keiretsu in Japan allows different stakeholders to become involved on an information basis in the governance of firms (Turnbull 2000c: 172, 210). This is consistent with the observations by Williamson (1985: 308) who stated that the involvement of stakeholders in the governance of a firm, "if it occurs at all, should be restricted to informational participation". However, Porter did not note the presence of compound boards in Germany and Japan in his recommendations for improving the competitiveness of US firms. He recommended to US policy makers and companies to 
appoint "customers, suppliers, employees and community representatives to the board of directors" (Porter 1992: 16-7). This recommendation would exacerbate conflicts of interest and be contrary to the observations of Pejovich (1990), Sternberg (1996) and Jensen (2000) that directors accountable to many constituents become accountable to no one.

US scholars developed the theory of the firm during the height of the ideological contest between capitalism and communism. It would have been unpatriotic for these scholars to entertain the possibility that markets were not the natural order of a free society. The failure of communism has reinforced the hegemony of market ideology with widespread political interest in privatisation based on the US model of a firm. The problems of using this model in the USA are identified by Jensen (1993), in Russia by Blasi and Gasaway (1993) and in Australia by Turnbull (1995a, b). The problems of the US model in either the US or former socialist economies, are outlined by Shleifer and Vishny (1996), and Turnbull (1993).

Theories of the firm that are enunciated by US scholars become less relevant when economic transactions are mediated by cultural priorities; business related associations, trade, and vocational, family, social and political networks. That is when transactions governed by family relationships and associations become more prominent as is found continental Europe, Japan and other Asian countries as reported by Hollingsworth and Lindberg (1985), Analytica (1992), Hollingsworth et al. (1994) and Hollingsworth and Boyer (1997). However, "the social governance of markets" in the USA is not insignificant as detailed by Bruyn (1991). The operating advantages of a greater reliance on associations and networks in the governance of firms has been reported by Aoki (1998), Franks and Mayer (1993), Gilson and Roe (1993), Kester (1992), and Turnbull (1995b). Blair (1995), and Fukao (1995: 74, 77-8), with Porter (1992: 16-7) recommending that firms in the USA establish what are in effect network relationships with their stakeholders.

The lack of recognition by scholars that there are modes of organising transactions outside markets and hierarchy and the hegemony of market ideology has resulted in there being no accepted theoretical framework for comparing systems of corporate governance within or between cultures as noted by Demb and Neubauer (1992). Radner (1992: 1384) goes further to state, "I know no theoretical research to date that compares the relative efficiency of hierarchical and non-hierarchical organizations within a common model”. More generally, Jensen (1993: 873) observed that: "we're facing the problem of developing a viable theory of organizations". This problem has been identified by a number of other leading workers in the field. In relation to existing theories, Zingales (2000) states that, "they seem to be quite ineffective in helping us cope with the new type of firms that are emerging".

Coase (1991b: 72) saw the need for "a more comprehensive theory" and stated that "theory is outrunning our knowledge of the facts in the study of industrial organization and that more empirical work is required if we are to make progress" (Coase 1991a: 451). North (1985: 572) noted that there is an "additional dimension currently missing in the discipline of economics". Williamson (1985: 7) quoted another scholar who stated: "a new micro theory would arise which 'will, and should, deal with the economic foundations of organization and institution, and this will require us to have an economics of information and a more sophisticated treatment of the technology of transacting'". Williamson (1990: xi) sees the need for "observing the phenomena at a higher level of resolution". Williamson (1991: 10) noted that “In Demsetz's judgment, however, recent work — of team theory (Alchian and Demsetz 1972), agency theory (Jensen and Meckling 1976) and transaction cost kinds - has not gone far enough". Demsetz (1991: 159) stated that: "a more complete theory of the firm must give 
greater weight to information cost than is given either in Coase's theory or in theories based on shirking and opportunism which have not gone far enough".

Radner (2000: 623) states "There is a growing unease with the mainstream models of Homo economicus". The unease over the mainstream model is supported by the observation by Van Zandt (2000) that "A question that has eluded satisfactory general treatment is the comparison of the computational efficiency of the many organizational forms, including market mechanisms and bureaucratic structures, that are used to coordinate economic activity". In closing his survey of decentralized information processing in the theory of organisations, Van Zandt (2000) provides support for the approach proposed in this paper by stating that "Organizational theory from a management and sociological perspective has a long history of studying human organizations as information networks". However, these approaches have been based on using cost, rather than data as the unit of analysis.

Instead of giving "greater weight to information cost" this paper proposes that costs be replaced with bytes as the unit of analysis. In this way an "additional dimension currently missing in the discipline of economics" is introduced as proposed by North, and for "observing the phenomena a higher level of resolutions" as sought by Williamson. The development of this approach is presented in the following section.

\section{Relevance of Transaction Byte Analysis}

This section considers the relevance of using bytes as a basis for analysing firms. Recognition of information as an important component in developing theories of the firm is first considered. The way in which information is processed within and between humans is outlined. Physical limitations on the ability of humans to process information, described as "bounded rationality" are identified with its causes. The limited ability for humans to transact bytes is also identified as determining the form of firms and the form of communication within and between firms.

The central importance of information in micro-economic analysis is provided by Williamson (1985: 283) who states that, "The problem of organization is precisely one of decomposing the enterprise in efficient information processing respects". Williamson (1985: 282) recognised the cybernetic significance of technical and temporal specialisation of organisational information by quoting the work of Ashby (1960) and Simon (1962) who pioneered cybernetic analysis.

Cybernetics was established as a separate science in the middle of the $20^{\text {th }}$ century when Weiner coined the word from the Greek word for "steermanship" or "govern" (Oxford 1956: 2497). This makes cybernetics the science of governance. Weiner (1948) defined cybernetics as "the study of information and control in animal and machine". Beer (1959; 1966; 1985; $1995 \mathrm{a}, \mathrm{b}, \mathrm{c})$ pioneered the extension of cybernetics to management. ${ }^{1}$ The author has been

\footnotetext{
${ }^{1}$ Stafford Beer was a past president of the World Organization of General Systems and Cybernetics and a pioneering practitioner of management cybernetics. In Toronto, August 3rd, 1996 he reviewed Turnbull (1997b) and advised the author that he was not aware of cybernetics being applied to corporate governance. Beer's work involved communications and control within firms or bureaucracies, and was also based on information rather than bytes. President Allende retained Beer in 1971 to assist him in managing the Chilean economy. http://member.newsguy.com/ mayday/crypto/crypto6d.html http://pespmc1.vub.ac.be/:/CSTHINK. html
} 
extending the application of cybernetics to the governance of organisations (Turnbull 1997b, c) through TBA as developed in Turnbull (2000c).

Data can be transmitted in at least two ${ }^{2}$ ways. One way is through discrete changes as occur when an electric current is turned on or off to create a Morse code signal. The dots and dashes represent a binary code because it is made up of two elements. Digits such as zeroes and ones can represent the dots and dashes mathematically. Each zero and one represents a "binary digit" which was abbreviated to the word "bit" by Tukey in 1946 and who in 1958 coined the word "software" to describe the programs that ran computers that are mostly written in a binary code (Princeton 2000). Pictures can also be transmitted in binary code. Under a magnifying glass, newspaper photographs are seen as tiny dots of black ink interspersed with the white background of the paper.

The other way of transmitting information is through a continuous change in energy or movement of matter described as "analogue" transmission. Microphones pick up speech in this manner and transmit the information by phone or radio to a speaker. However, all analogue transmissions can be decomposed into digital form that can be analysed mathematically to detect and correct errors in transmission. It is for these reasons modern mobile phones, radio and TV communications use the digital forms of communications. Another advantage is that the rate at which data can be transmitted or processed can be quantified and described in bits per second. It is the orders of magnitude of data transmission that this paper is concerned with so the fact that exact measures may not be practical is not an issue in developing the TBA framework. The TCE framework is likewise not dependent upon measuring costs and has in many situations the additional problem of identifying and allocating relevant costs such as fixed and variable.

For Morse code to transmit a alphanumeric symbol a group of dots and dashes, or bits, are required to define a letter of the alphabet or number. A set of bits is defined as a "byte". Sets of bits (ones and zeroes), of a specific length, represent a value in a computer coding system. A byte is to a bit what a word is to a character, which is why a byte sometimes is referred to as a 'word'" (Newton's 2001: 109). A byte might represent a letter, number, punctuation mark or other typographic symbol. "The term generally is thought as designating a computer value consisting of eight bits" (Newton's 2001: 109) and is abbreviated to a " $\mathrm{B}$ ". The word byte is short for "by eight". The memory capacity of computers is measured in bytes. A thousand bytes, which is approximately $2^{10}(1,024$ bytes) is described as a Kilobyte and a million bytes ( $2^{20}$ or $1,048,576$ bytes) is referred to as a Megabyte. A Gigabyte is a thousand Megabytes or $2^{30}$.

Just as computers have limited ability to receive, store, process and transmit information and inter-net connections are limited by their physical capacity to process bytes, so are humans as outlined in Table 2. The two are directly comparable. It is not a metaphor. Most computers are designed to process data sequentially with one computation being taken at a time like adding up numbers one at a time. Computers can also be designed to process data simultaneously. Humans process data in both these ways as discussed below. But we need to define and relate a few terms first.

Information is meaningful data so all information can be measured in bytes. Knowledge is useful information so it can also be quantified in terms of bytes but more bytes are required to

\footnotetext{
${ }^{2}$ A third way of transmitting information is by "Qu-bits" that occurs in quantum computing. The position of an elementary particle or its energy state can be represented as both a zero and a one at the same time (Kurzweil 1999: 110).
} 
determine its usefulness. Likewise, wisdom depends upon when and how knowledge is applied and so requires many more bytes to relate present situations to those in the past to compare how the application of knowledge may affect outcomes. A simplistic outline of these relationships is set out in Table 1 below.

Like computers there are two ways in which the brain processes bytes. One is through the recognition of patterns, which requires massively parallel computations and the other is through sequential analysis. It is pattern recognition that is most prevalent in all living things. The ability to undertake sequential analysis is most highly developed in humans and this only occurred recently in our evolutionary development.

Kurzweil (1999: 103) states:

The human brain has about 100 billion neurons. With an estimated average of one thousand connections between each neuron and it neighbours, we have about 100 trillion connections, each capable of a simultaneous calculation. That's rather massive parallel processing, and one key to the strength of human thinking. A profound weakness, is the excruciatingly slow speed of neural circuitry, only 200 calculations per second. For problems that benefit from massive parallelism, such as neural-net-based pattern recognition, the human brain does a great job. For problems that require extensive sequential thinking, the human brain is only mediocre.

This speed of calculations in the brain compares with the thousands of billions of sequential calculations per second (Gigahertz) of desktop computers. As anticipated by Kurtzweil computers are now surpassing the capacity of humans to carry out massively parallel calculations required for complex pattern recognition. It is through recognising patterns rather than making calculations that humans succeed in undertaking complex tasks.

Kurzweil gives the example of a ten-year-old child who catches a ball. Knowing the speed and direction the ball is thrown, and many other factors, it is possible to calculate where the ball will be at any time in much the same way an anti-missile rocket calculates where its target will be when they meet. However, the child has no computer, pen, paper and knowledge of calculus or simultaneous equations to make the calculations within a second or two to catch the ball. Success depends upon training "her neural nets' pattern-recognition ability" (Kurzweil 1999: 79).

The connections between neurons are called synapses and these connections develop in strength according to their use. Data and so information, knowledge and wisdom is stored through the pattern of both the architecture and strength of the connections. To solve problems

Table 1 Terms and relationships

\begin{tabular}{ll}
\hline Term & Description \\
\hline Bits & Represented by an "0" or "1" (Binary digit) \\
Bytes & Group of 8 bits (Group of eight "0"s and/or "1"s) \\
Data & Collection of bytes (Collection of groups of "0"s and/or "1"s) \\
Information & Data that provides meaning to an agent. It requires associating stored data to be related to \\
& new data and the context in which it is received. \\
Knowledge & $\begin{array}{l}\text { Information associated with stored and/or external contextual information that can be used } \\
\text { to achieve a task or goal. }\end{array}$ \\
Wisdom* & Knowledge of when and how to use knowledge \\
\hline
\end{tabular}

${ }^{\text {a }}$ Specific for each individual 
efficiently without the need for calculations, humans have to train their synapses to fire and so develop appropriate patterns. This creates a pattern of response for future use. The build up and reinforcement of the ability of synapse to fire allows a person to make physical responses based on pattern recognition rather than by logical reasoning. The process of conditioned reflex action is applicable to executives as well as children.

The neurological training processes can be considered the "set up cost" of achieving proficient responses to environmental situations. This is how people learn to drive cars and why an investment of time in safety drills are required to allow people to react automatically or "instinctively without thinking" as may be required. It also provides a rationale for teaching business by the case method to lay down patterns of situations and responses in the neural nets of students. Chief executives and company directors are no exception.

Kurzweil (1999: 79) also points out that, "One key to intelligence is knowing what not to compute. A successful person isn't necessarily better than her less successful peers at solving problems; her pattern-recognition facilities have just learned what problems are worth solving." It is by pattern recognition that humans solve most problems.

Another way of reducing an element of "bounded rationality" is by incurring the "set up cost" of neurological conditioning so responses can become automatic, like driving a car, rather than needing to work out every response to changing situations. Another element of bounded rationality is the limited ability of humans to transact bytes. This arises from limited information processing in the organs that detect signals or in the nervous system and the brain that respond to the data. The cybernetic principles used by the brain to minimise these problems with network governance can also be used by organisations and will be discussed in the next section.

The data required to create living things, including humans and their brains is stored in the pattern of molecules found in DNA. This type of data is described as "process information" (De Vany 1998: 3). "Structural information" (De Vany 1998: 3) explains how a structure operates and is depicted by the architecture of the formal communication and control channels of a firm. He describes how the quantity of each type of data sets can be measured.

Knowledge is retained in the brain by the state of synapses connecting the neurons. Kurzweil (1999: 119) estimated that "about a million connections per chunk" of knowledge is required. With 100 trillion connections in the brain, it has the capacity for 100 million chunks of knowledge. Each chunk may be recognition of objects, a face, smell, meme, word, phrases and so on. Kurzweil (1999: 119) reports that "the number of concepts - 'chunks' of knowledge - that a human expert in a particular field has mastered is remarkably consistent: about 50,000 to 100,000 ". This is only a small fraction of the general knowledge of a typical human. But it indicates how and why the knowledge and reasoning of humans is subject to limits, which need to be recognised in analysing the operations of firms.

Like humans, computer chips have limited information processing capacity and memory. So just as computers need to be designed within the operating capabilities of their components, so do social organisations need to be designed to recognise the operating limitations of people. The need to limit the "span of control" of managers to say half a dozen people is a simple example of the need to design organisations to meet the limited ability of individuals to process bytes and manage complexity. It is these limits that force the creation of hierarchies and $\mathrm{M}-$ Form firms. Egelhoff (1982) has shown how the information-processing requirements determined the strategy and structure of multinational corporations and Galbraith (1973) has also shown that the information processing needs of an organisation determined its form. Daft and Lendel (1984) found that managers selected a medium of communication so that it can carry 
the richness of the information needed to understand the complexity of the problems being confronted.

The efficiency and effectiveness of computers and their chips is dependent upon the architecture of their internal circuits as well as the architecture of how both the chips and their computers are connected. Their ability to perform different tasks can be improved by adopting a specialised architecture for particular applications or situations. This also applies to the communication and control architecture of organisations as investigated by Simon (1962), Galbraith (1973), Williamson (1975), Bernstein (1980), Egelhoff (1982), Daft and Lengel (1984).

Williamson (1975: 45-6) noted that "a change in organizational structure may be indicated" when individuals are exposed to "information-processing limits". By these words, Williamson is explicitly acknowledging that organisations need to be designed according to the ability of people to transact bytes. He is also providing an example of using an informational perspective to analyse organisations. This perspective was used by Turnbull (2000c: 130, 221) to identify how Mondragón firms present an outstanding example of how the architecture for creating and managing complexity in nature, described as "holons" and "holarchies" (Koestler 1967), provided them with competitive advantages. TBA provides a basis for comparing the architecture of nature with the architecture of organisations and providing insights how the competitive advantages are obtained (Turnbull 2000a, c, d; 2001; 2014a). The problem with hierarchies is that they simplify complexity by eliminating and concentrating data while networks distribute decision making to the lowest level that allows multiple data cross checking.

To provide a basis for evaluating and/or designing the cybernetic architecture of firms the physical limits of humans to transact bytes needs to be identified. The rate at which individuals can receive, process and transmit bytes is indicated in Table 2, 'Human constraints in transacting bytes'.

Table 2 indicates the rate at which the five conscious human senses described as "input channels" can transact bytes to the brain. The rate is determined by the physical properties of the respective organs. Because humans cannot usually control either their smell or taste the

Table 2 Human constraints in transacting bytes. ( $\mathrm{K}=$ Kilobytes, $\mathrm{M}=$ Megabytes)

\begin{tabular}{|c|c|c|c|c|c|c|}
\hline INPUT CHANNELS & Smell & Taste & Touch & Sound & Sight & CONSTRAINTS IN HUMANS \\
\hline $\begin{array}{l}\text { Channel capacity in } \\
\text { bytes } / \mathrm{sec}^{\mathrm{a}}\end{array}$ & $<10$ & $<15$ & $<15$ & $100 \mathrm{~K}$ & $1,000 \mathrm{M}$ & $\begin{array}{l}\text { TO TRANSACT BYTES } \\
\text { CREATED BY: }\end{array}$ \\
\hline NATURE OF & 1 & \multicolumn{4}{|c|}{ RECEPTION through organs } & Physiology \\
\hline TRANS-ACTING & 2 & \multicolumn{4}{|c|}{ STORAGE through nervous system } & Physiology \\
\hline BYTES IN & 3 & \multirow{2}{*}{\multicolumn{4}{|c|}{$\begin{array}{l}\text { PERCEPTION/UNDERSTANDING } \\
\text { through the activation and } \\
\text { strengthening of neural networks } \\
\text { which correlate current patterns } \\
\text { with previous ones }\end{array}$}} & Neurology, experience, training, \\
\hline HUMANS & & & & & & $\begin{array}{l}\text { motivation and psychological } \\
\text { status }\end{array}$ \\
\hline & 4 & \multicolumn{4}{|c|}{$\begin{array}{l}\text { INSIGHTS/KNOWLEDGE through } \\
\text { sequential processing in neo-cortex } \\
\text { limited to around } 200 \text { calculations } \\
\text { per second (Kurzweil 1999: } 103 \text { ) }\end{array}$} & $\begin{array}{l}\text { As above plus size and architecture } \\
\text { of neo-cortex and psychological } \\
\text { status }\end{array}$ \\
\hline & 5 & \multicolumn{4}{|c|}{$\begin{array}{l}\text { EXTERNAL RESPONSES } \\
\text { transmitted by movement and } \\
\text { vocal chords }\end{array}$} & $\begin{array}{l}\text { Proximity/distance, environmental } \\
\text { conditions, culture, literacy and } \\
\text { numeracy }\end{array}$ \\
\hline OUTPUT CHANNELS & Touch & Signs & Writing & Sound & Speech & Information can be received 10,000 \\
\hline $\begin{array}{l}\text { Channel capacity in } \\
\text { bytes/sec }\end{array}$ & $<15$ & $<15$ & $<15$ & $<100 \mathrm{~K}$ & $<100 \mathrm{~K}$ & $\begin{array}{l}\text { faster than the rate at which it } \\
\text { can be transmitted }\end{array}$ \\
\hline
\end{tabular}

${ }^{a}$ Sources of channel capacity; Cochrane $(1997 ; 2000)$ 
five "output channels" depend upon physical movement and/or auditory signals. The physical activities being touch, movement and writing and the auditory signals being speech or other sounds. Beside the reception and transmission of bytes, which are numbered 1 and 5 respectively in Table 2, the Table identifies three other ways bytes are transacted within humans. One-way numbered 2, is the storage of bytes, with number 3 being perception and understanding based on pattern recognition. Number 4, is the sequential processing of bytes to assist in obtaining insight and knowledge. The right hand column of Table 2 identifies the physical constraints on transacting bytes for each of the five conscious processes. Pheromones represent an unconscious communication channel.

The data presented in Table 2 shows that the fastest rate at which individuals can transmit bytes is limited to speech and movement. This makes the transmission of information around 10,000 times slower than the reception of information by sight.

Beside the physiological limitations in transacting bytes, there are neurological limits, which is described as "bounded rationality". The term arises from Hayek (1945: 527) who noted that, "The problem of a rational economic order is trivial in the absence of bounded rationality limits on human decision makers". Williamson (1975: 21) noted that "Bounded rationality involves neurophysiological limits on the one hand and language limits on the other". Williamson (1975: 21) explains that:

The physical limits take the form of rate and storage limits on the powers of individuals to receive, store, retrieve, and process information without error. Simon observes in this connection that "it is only because individuals human beings are limited in knowledge, foresight, skill, and time that organizations are useful instruments for the achievement of human purpose" quoting Simon (1957: 199).

The comments by Hayek, Williamson and Simon quoted above support the view that it is information, rather than costs that provide a reason for organisations to exist for undertaking complex tasks. In other words, firms emerge as way a way for individuals to reduce the number of bytes they need to transact to co-ordinate complex tasks efficiently. That is, firms emerge as a way to reduce bounded rationality and information overload. Firms may also emerge for other reasons such as to increase physical effort or allow services to be provides at all hours and/or in many ways.

The limited ability of individuals to receive, internally transact and transmit bytes shown in Table 2 must necessarily limit the ability of individuals to communicate and process data, information, knowledge and so wisdom. Just as teamwork is required for physical activities like lifting heavy loads, as discussed by Alchian and Demsetz (1972), joint production is also required for intellectual activities whose complexity exceeds the ability of an individual to handle. In either, case bytes need to be transacted to achieve co-ordination.

However, even if firms are formed to increase the physical output of individuals, they could not be effective without information being exchanged to coordinate the activities between the various individuals. So even in these situations firms could not exist without the transaction of bytes. In the simple case of two men lifting a heavy load some communication is required to solicit assistance. Non-verbal communication may then be used as the principal method of achieving teamwork by coordinating load sharing. While costs may be involved in soliciting assistance they are not relevant in achieving or managing the teamwork required for lifting a load.

As the physical exertion or complexity of co-ordination increases the need to transact bytes will increase and becomes increasingly important for the task to be carried out efficiently. 
Firms, or any other type of social organisation, cannot exist without the transaction of bytes between people.

Likewise, the need to communicate between individuals within a firm can be a more crucial concern in determining its operations than cost. This is illustrated by the explanation by Williamson (1985: 279-283) of why firms changed from U-Form to M-Form structure to reduce information overload of head office. The cybernetic architecture of European firms with two three of more boards is presented in Turnbull (2000c: 173).

The use of bytes as the unit of analysis allows the analysis of firms with more than one board to be undertaken. It also allows firms with compound boards to be compared with those with single boards and network firms as illustrated by Turnbull (2000c: 245). The use of bytes as the unit of analysis provides a way to "compares the relative efficiency of hierarchical and non-hierarchical organizations within a common model" as sort by Radner (1992: 1384).

The use of bytes instead of costs as the unit of analysis, establishes a physical basis to identify when bounded rationality will arise from the limited physiological and neurological capacity of individuals to transact bytes as indicated in Table 2. The economising considerations of TCE may still apply. However, the need to economise bytes provides an over-riding consideration in determining the most effective organisational architecture for the firm to achieve its purpose.

A fundamental concern of TBA is to consider the limits of human information processing ability. TBA provides a way to identify how firms and compound boards provide strategies for decomposing decision making labour so individuals can operate within their information processing ability. An analysis of how the architecture of Mondragón cooperatives decompose the decision making of a unitary board into four components is provided by Turnbull (2000c: 244-245).

Advances in understanding the capacity of the brain to processes different types of information also become relevant in evaluating the architecture of institutions. Evolutionary biologist, Robin Dunbar (1993: 685) reports that the capacity of the human neocortex limits the maximum number of people an individual can establish social bonds and trust with to around 150 . He also reported research which suggested that 500 people represents a "critical threshold beyond which social cohesion can be maintained only if there is an appropriate number of authoritarian officials" (Dunbar 1993: 687). These findings provide another reason why firms have diminishing return to scale in addition to the three identified by Coase (1937) discussed in Section 2.

The analysis of Coase was made in the context of U-form firms, as M-form firms had not then evolved. The evolution of $\mathrm{M}$-form, $\mathrm{H}$-form, network and holonic form firms provide a basis for reducing the number of people involved in the need to establish trust and social cohesion in a firm. The findings of Dunbar become more important in the architecture of a firm as the need for trust and social cohesion increases in the work place to provide sustainable and/ or competitive advantages.

TCE is based on a normative view that cost should be economised. TBA has an instrumental basis that bytes need to be economised to recognise the physical limitations of people and devices to process information. The importance of minimising data processing is indicated by the human brain consuming $20 \%$ of body energy but representing only $2 \%$ of body mass. When costs are a proxy for information, TBA becomes a microelement of TCE. Bytes provide a way for "observing the phenomena at a higher level of resolution" as sought by Williamson (1990: xi) and the other concerns by scholars on the theoretical shortcomings noted in Section 2. But importantly TBA introduces the laws of cybernetics to all social institutions as considered in the next section. 


\section{Cybernetic Evaluation of Firms}

This section introduces three cybernetic principles to the governance and regulation of firms. The principles show why a firm governed by a unitary board is at a disadvantage in: (i) overcoming bounded rationality in decision making, (ii) obtaining sufficiently accurate information, and (iii) exercising control to manage complexity.

One problem in applying the concepts of cybernetics to social institution is the ambiguous meaning of common words like "control". For example, Etzioni (1965: 650) and Downs (1967: 144) use the word 'control' in the sense of meeting some standard of performance. In other words, control cannot be achieved without there being a defined standard of performance and that feedback information is provided to identify variation of actual performance from that required. Other writers use the word control in a much more restricted way such as Tannenbaum (1962: 5) who states that it is "any process in which a person or group of persons or organisation of persons determines, ie. intentionally affects, what another person or group or organisation will do". In short, control does not require either a standard to be established or feedback information on if the standard is achieved.

To avoid ambiguity, the Tannenbaum meaning will be adopted with the word "regulate" being used to convey the meaning described by Etzioni (1965: 650), Downs (1967: 144) and Ashby (1968: 195). It is also useful to distinguish between the two different meanings in social institutions where instructions, commands and orders can be made without consideration of what may be achieved. The use of different words is also of value in analysing the conditions for establishing self-regulation and self-governance in social institutions as presented in Turnbull (2000c: 118). Precision in the meaning of the words was essential for the early pioneers in cybernetics who founded the science in mathematics.

Mathematician von Neumann (1947) identified the advantages of introducing variety in decision-making centres. He was one of the founders of the science of cybernetics and explained how the brain could obtain reliable results from unreliable elements. Beer (1995b: 448) described this as the von Neumann theorem, which states, "outputs of arbitrarily high reliability can be obtained from computing elements of arbitrarily low reliability if the redundancy factor is large enough". This observation is quite general and applies to social organisations. In organisations this means that errors in decision-making can be diluted to irrelevance if there are sufficient number of decision-makers. This explains how network governed organisations can become more resilient than hierarchies considered by Coase (1937).

The von Neumann theorem explains why authoritarian management that does not accept a plurality of views is more exposed to incorrect decision-making. A compound board, with the diverse views of its stakeholder constituencies and a plurality in its components reduces the risk of sub-optimal decision-making. This is independent of any motivation advantages that my be obtained by involving a greater number of people in decision making or decomposing decision making labour by using a compound board to introduce distributive intelligence.

Shannon, another pioneer of cybernetics, made a somewhat similar observation. Shannon (1949) showed that accurate information could be obtained when noise, distortion and bias exist in a communication channel by establishing a variety of information channels. Beer (1995b: 282) states:

For example, if management were compelled to rely on the information it required through "orthodox" channels of communications, it would certainly never have anything like requisite variety for controlling the company - for the simple reason that the orthodox channels could not transmit it. 
To correct for noise, errors, distortions and biases, a variety of independent channels of information are required. By having a variety of independent sources of information, the integrity of information can be established to overcome the problems of lost or distorted information as described by Downs (1967: 116-8). The need for collaborating evidence is a common feature in many types of investigations and many CEOs establish informal information networks to supplement formal channels of reporting. However, idiosyncratic informal channels do not represent a systemic process for assuring the integrity of management information. Ways of establishing a variety of formal channels independent of management are described by Turnbull (1997a; 2000b c, d; 2016).

Both the CEO and directors of a unitary board are generally at a disadvantage in having access to systemic process for obtaining the "other side of the story" of any strengths, weaknesses, opportunities and threats (SWOT) in either management or the business. Hence the recommendations of Porter to include diverse stakeholders in the information system of firms to provide competitive advantages. However, the inclusion of diverse stakeholders on a single board introduces conflicts and accountability problems reviewed in Section 2.2.

Another fundamental law of cybernetics is the related 'Law of Requisite Variety' that states "the variety of a regulator must equal that of the disturbances whose effect it is to negate" (Ashby 1968: 202). Another formulation by Beer (1995a: 41) is "that control can be obtained only if the variety of the controller (and in this case all parts of the controller) is at least as great as the variety of the situation to be controlled."

Beer describes this as Ashby's Law, which he observed is poorly understood. To overcome this problem, Beer (1995c: 84-96) provides several examples to communicate its meaning. Beer (1995b: 279) uses the football team metaphor to illustrate the law. The same number of players is required to provide an even chance for players in one team to compete with another. A team without sufficient players, (ie. requisite variety) becomes uncompetitive, and likewise, firms. This is why "complete centralised control is impossible in any complex system" (Mathews 1996a: 41).

In the words of Ashby (1968: 207) "Only variety can destroy [i.e. control] variety". Another formulation of the law of requisite variety is that complexity is required to manage complexity. Non-trivial firms with a unitary board do not meet the test of possessing requisite variety in their information and control channels and so their competitive capabilities cannot match those with an appropriately designed compound board. Ashby's law of requisite variety explains what Hock (1994: 8) refers to as the "second law of the universe: nothing can be made simpler without becoming more complex". Persson et al. (1996) and Diermeier and Myerson (1999) have shown that an appropriate division of power as is inherent in a compound board can increase the welfare of all stakeholders.

Another insight of Asbhy is the impossibility of amplifying regulation. In discussing the capacity of any controller to regulate/manage variables, Ashby (1968: 268) states: "The Law of Requisite Variety, like the law of Conservation of Energy, absolutely prohibits any direct and simple amplification but it does not prohibit supplementation". One man would not be able to directly load hundreds of heavy containers on to a ship but the Law of Conservation of Energy does not prohibit him from supplementing his energy by using a crane.

Likewise, supplementation of regulation depends upon one regulator being used to regulate many others. One man could not regulate the temperatures in a 100-room hotel as the weather changed during each day if he had to adjust the heaters/coolers in each room directly. However, if each room had a thermostat, which sensed changes in the air temperature of each 
room and made adjustments, accordingly to its air conditioning system then one man could control the temperature of all rooms.

The law of requisite variety explains why it is impossible for governments to regulate the complexity of society without supplementation. However, lawmakers are not aware of this limitation and so keep on introducing more and more prescriptive laws in an effort to introduce greater regulation. The result is more red tape to frustrate business, more cost to government with problematical protection for consumers and investors for whom the laws are intended to protect.

Supplementation is essential because in the regulation of firms, one law/size does not fit all. It is by trying to protect the public for all firms in all situations that the law gets so complex. Instead of prescribing details/temperature for each firm/room, the law need only prescribe the processes by which each firm/room is regulated. Prescription is still needed, but it is a more basic level. That is to introduce elements of self-regulation to ensure that supplementation is provided for each firm.

It is by this process of supplementation that the architecture of the human brain with its hundred trillion $\left(10^{15}\right)$ connections between its 100 million neurones $\left(10^{8}\right)$ is created by the DNA code which contains less than one hundred thousand $\left(10^{5}\right)$ genes (Kurzweil 1999: 203, 323). The DNA molecule contains the design instructions or "process information" (De Vany 1998) to not only build the human brain but all the rest of the body according to the embedded "structual information".

A former Vice President of the USA suggested that the reason for the lack of knowledge about efficient regulation in the USA in the "information age" is that only nine of the 535 members of Congress have any professional education in technology (Gore 1996). Another reason could be that social scientists are not sufficiently familiar with the theory and practice of self-regulation to understand why it cannot work with the dominant form of institutions in advanced economies. This dominant form is based on centralised information and control without checks and balances, self-correcting feedback information and control channels to allow self-governance in either the private or public sector.

Gore (1996) proposed that governments should "imprint the DNA" of social institutions to make them much more self-regulating to minimise the role of government. This could be achieved by the government making it a condition for social institutions to exist that they establish self-governing constitutions. How this process could be introduced, is illustrated by the Mondragón bank that makes it a condition for financing any new firm that the firm adopts a self-regulating constitution with a compound board as described in (Turnbull 2000c: 118). By making the primary building blocks of their system self-regulating the MCC provides a basis for the whole system to become self-regulating and self-governing as discussed in the next Section. The introduction of corporate constitutions with self-regulating features could be introduced to market economies by using tax and other incentives (Turnbull 1997a; 2000a; 2014b).

The law of requisite variety explains why attempts by government and their regulators to directly control their citizens, corporations and social activities generally are getting more and more complex. The ever-increasing size and complexity of corporate law in Australia provides one example. More pages of prescriptive detail is added every year to make it one of the most detailed and lengthy in the world. In 2016 political leaders in the UK, US and Australia promoted the need for reducing and simplifying regulation. While the rhetoric of modern law reform is to make it more efficient and competitive, the opposite is taking place.

Simon (1962) showed that the most effective way to create of manage complex systems is through establishing "sub-assemblies", "stable intermediate forms" or "nearly decomposable 
systems, in which the interactions among the sub-systems are weak, but not negligible". These "sub-assemblies" are described in this paper as an "almost self-governing components" or meet the test of being a "holon" as defined by Mathews (1996a: 34).

\section{Comparison of Frameworks}

TBA is relevant to all types of institutions whether or not they are concerned with costs. When costs are relevant, they act as a proxy for bytes. In the special case when information about prices or costs are involved, TBA becomes limited to the information of economics. In this way, TBA both subsumes TCE and becomes a microelement of it while also having the ability to take into account non-economic information on which markets are based.

Costs are social constructs. The measurement of any transaction cost depends upon separating the set up cost from re-occurring costs. Even when costs are identified they are measured in another social construct called money. Modern fiat money, unlike bytes, cannot be defined in terms any physical quantity. So even if it may be impractical to identify the number of bytes involved in the transmission and reception of data between individuals, bytes exist as a physical manifestation that could in theory be identified and measured. Currently there are physical limitations on the volume bytes that can be transacted by any person, organisation or machine. This makes bytes a more rigorous unit than costs to investigate operations within firms and the ways in which they are governed by one or more boards. Perhaps most importantly, the use of bytes provides a way to investigate the limited ability of individuals to process information and so 'bounded rationality' which is responsible for "the problem of rational economic order" as noted by Hayek (1945: 527).

The economic literature recognises what is described as the "economics of information" (Molho 1997). In this literature the units of analysis are costs not bytes. The economics of information is based on the normative view that costs should be minimised. The need to minimise bytes is not based on a normative view but on an instrumental one that arises because individuals are subject to physical limitations in their ability to transact bytes (Refer to Table 2). However, TBA can also be used to support the normative considerations of the economics of information based on the social construction of transaction costs. So while TCE is based on the economics of information, TBA is based on the data of economics. Because bytes are involved in any type of human co-ordination, TBA provides a way of comparing various theories of the firm.

TBA provides a way to investigate how communications between people affects the performance of any type of organisation. TBA also shows how cybernetic principles provide a basis for identifying "organisational advantage" which Nahapiet and Ghoshal (1998: 261) say is "as yet inadequately understood." The TBA framework is universal. It can be applied independently of organisational form, structure, purpose or social context. This allows it to be used in evaluating alternatives to privatisation as undertaken by Turnbull (2007). By allowing organisational analysis to be grounded in the physiological and physiological characteristics of people and the laws of cybernetics, TBA provides a basis for evaluating or designing institutions.

As information can alter the behaviour of people, people become both a dependent and independent variable. The variability of people and the variability in the ways in which people 
transact bytes become the focus of concern. Because people have limited ability to receive, store, retrieve, analyse and transmit data, the effectiveness of firms becomes dependent upon keeping the capacity of people to transact bytes within their capabilities. The communication and control architecture of firms also needs to compensate for any variability in human capabilities and motivations. This makes the effectiveness of firms, dependent upon how well their communication and control architecture allows individuals to operate within their cybernetic limits and compensate for human variability.

While much of TBA is grounded in the work of Williamson, TBA creates a different framework of analysis. To use the words of Kuhn (1970: 80) who was describing a "paradigm shift", TBA "involves the same bundle of data as before, but placing them in a new system of relations with one another by giving them a different framework". The TCE framework is based on "transaction costs" while the TBA framework is based on "bytes". The differences between the TCE and TBA frameworks are outlined in Table 3, 'Comparison of TCE and TBA boundaries'.

TBA extends the boundaries of analysis of TCE as shown in Table 3. Just as Newton's "Laws" of motion are relevant to only limited situations covered by Relativity Theory, so is TCE relevant to only limited situations covered by TBA.

Another limitation of TCE, noted in the first row of Table 3, is that it assumes firms are not labour managed. Williamson (1985: 265) states that he, "is mainly preoccupied with assessing capitalist modes of organisation". He acknowledges the existence of Mondragón enterprises but dismisses them as an "experiment" but notes that labour managed firms require "further study". As indicated in row four of Table 3, the relationship of people is master/servant or competitive whereas with TBA the relationship can be competitive and/or cooperative consistent with the observation of Wearing (1973).

However, even with capitalist firms, Barney and Ouchi (1986: 8) note that there are "theoretical and empirical anomalies". They go on to say that, "...the search is on for a more

Table 3 Comparison of TCE and TBA boundaries

Framework of analysis $\rightarrow$

TCE (Coase/Williamson)

For-profit firms with shares not labour managed

2 Subject of analysis

3 Unit of analysis

4 Relationship of people

5 People behaviour

6 Objectives

7 Basis for objective

8 Modes of governance

9 Communication and control through:

10 Firms of two or more people exist because:
Normative to reduce costs

Markets, hierarchies and hybrids of both

Markets and hierarchies

Markets fail to provide information economically
TBA (Developed by the Author)

Any social organisation, including any type of firm

People and the quanta (bytes) of data they process

Bytes

Family/clans, associations, networks, public or private hierarchies and markets

Any eg. Altruistic $\sim$ self-interest, etc.

Anything. (For firms, economising the transaction of bytes by people while compensating for errors with redundancy)

Physical limits in transacting bytes

Any combination of the six co-ordinating mechanisms listed in row four above.

Senses, semiotics, language and numbers

Complex tasks can be carried out with individuals transacting less bytes. 
general framework, a framework that will include the insights of the traditional theory, but will place those insights in a context that allows the theorist to explain a wider diversity of economic and, particularly, organisational phenomena". They identified the need for "a new paradigm for understanding and studying organizations". TBA is presented as such a framework grounded in the physiological and neurological limitations of people to transact bytes and the science of cybernetics.

A fundamental difference between the two frameworks is that the subject of analysis of TCE is the social construct of "transaction cost" while TBA is founded on the operating characteristics of people and their physical limitations to handle bytes as shown in the second row of Table 3.

It was Commons (1934: 4-8) who suggested, "that the transaction is properly regarded as the basic numaire of analysis". This suggestion was made some 14 years before Wiener (1948) identified the science of cybernetics and the later development of the concept of bytes. In any event the discipline of economics is based on the social constructs of costs and prices, which are assumed, or asserted to provide the basis for allocating resources - an assumption questioned by Dallas (1988: 37). Although bytes can be a sub-set of costs and prices, they were, and may still be, considered to be outside the discipline of economics. But as discussed by Klaes (2000) the description of a transaction and its cost has changed over the years with little agreement between the various writers.

TCE is based on firms being an "authority system", (row four of Table 3) as assumed by Coase (1937) and that they existed because they reduced the cost of governing transactions through the market. TBA extends the type of relationships between people to any of the six types shown in row four of Table 3 as identified by Hollingsworth (2000: 607). This extension allows the relationship of people on boards to be analysed. The TBA framework also provides a basis for developing a more comprehensive, compelling and relevant reasons why firms exist as indicated in row ten of Table 3 discussed later.

The subject of analysis (shown in row two of Table 3) creates different objectives in row six with TCE based on economising costs, while the concern of TBA in firms is to keep people operating within their data processing limits while compensating for errors. TCE assumes that people are opportunist and self-interested, while with TBA people may be altruistic, selfinterested or possess any other type of behaviour shown in row five of Table 3. As noted above, belief that costs should be minimised is a normative view of TCE, which is questioned by scholars such as Alchian and Demsetz (1972) and Dallas (1988) because of the difficulty of senior managers in non-trivial firms to possess data about costs or possess the will to reduce costs. This view is presented in row seven of Table 3, which notes that the reason for TBA objectives are grounded in the physical (physiological and neurological) limitations of people to transact bytes.

TBA recognises that transactions can be governed through six rather than the two methods recognised by TCE in row eight of Table 3. Communication and control in the Coasian/ Williamson framework is through "the limited institutional repertory" of markets and/or hierarchies rather than the six types of institutions identified by Hollingsworth (2000: 607). The channels of communication and control are detailed in row eight of Table 3. The additional institutional repertory is outside the discipline of economics and commerce and so, like bytes, is outside the field of vision of theorists from these disciplines.

However, research into comparative corporate governance by Porter, is supported by the perspective of Hollingsworth (2000). The high level US Competitiveness Policy Council commissioned Porter because of there was concern that US firms were not as competitive as 
those in Japan and Germany during the 1980s. This led US corporate governance scholars to study other cultures at the beginning of the 1990s. One result was a report by Porter (1992: 167) recommending reform of the US system of corporate ownership and control so that it would more closely follow the practices of other cultures. Blair (1995: 322) and Fukao (1995: 74, 77, 78) of the Brookings institution have since supported his recommendations.

In discussing the theory of the firm Winter (1991: 179) referred to the, "present theoretical chaos". Chaos was noted by Kuhn (1970: 77) as a "...precondition for the emergence of novel theories..." and for the need for finding a new paradigm as proposed by Barney and Ouchi (1986). Winter (1991: 193) went on to observe, "In the past half-century, it has been clearly demonstrated that the economy is much better at changing itself than economists are at changing their minds”. Williamson (1991: 11) states: “...Winter like Demsetz, also emphasises the importance of knowledge acquisition and its utilisation in future work on the theory of the firm". Williamson (1990: xi) supported the suggestion by Simon (1984: 40) that theorists should, "find techniques for observing the phenomena at a higher level of resolution". He then poses the question, "How micro is micro?" This paper posits that "bytes" present an answer to this question and provides a foundation for both establishing and grounding a "science of organisation" in the science of cybernetics. In this way Bytes extends cybernetics into becoming the Science of Governance (Turnbull 2002b, 2008).

In a "Search for new foundations" for a theory of a firm, Zingales (2000) raised four questions that any new theory would need to answer. His first was: "The fundamental question that a new theory of the firm should address, then, is how an organization succeeds in acquiring power that differs from 'ordinary market contracting between any two people' (Alchian and Demsetz 1972: 777)". Alchian and Demnsetz use the word "power" in the sense of a firm (not an organization as referred to by Zingales) being able to "manage and assign workers to various tasks?" That is, Alchian and Demnsetz are assuming that a firm is a separate entity from its workers and that it represents an authority system that exerts power over workers.

However, a major reason for Zingales to seek "New foundations" was his view that the nature of firms has changed so both these assumptions may not necessarily hold. Zingales explained:

The de-integration of the firm and the growing importance of human capital are changing the terms of the problem. Power and rents are not concentrated at the top of steep pyramid; they are sprinkled through out the organization, even outside the legal boundaries of the firm, as is the case for crucial independent supplies.

Zingales then went on to explain that "These changes make new firms more similar to cooperatives, rather than to traditional corporations". Some contemporary firms have power so diffused that they represent a network type of organisation discussed by van Alstyne (1997); Craven et al. (1996); Jackson (1996); Nohira and Eccles (1992); Podolny and Page (1997). Mathews (1996b: 116) points out that joint ventures, strategic alliances, associations and networks represent "economic entities which have a coherence, a structure and an individuality of their own" and that "a network or association of firms may itself be considered a firm".

For example, the Mondragón Corporación Cooperativa (MCC 2015) produces its own financial statements yet it is made up of network of independently owned 16 groups, each managed by a compound board with four components. Each group in turn is made of many independently owned component firms with each possessing a compound board with five components (Turnbull 2000c: 207). The compound boards of the primary component firms introduce intra-firm networks. 
The primary "independent" MCC firms are industrial cooperatives owned by their workers so the employees are both principles and agents. Primary cooperatives are free to leave the $\mathrm{MCC}$ if they wish and some have done so in a similar manner individual workers are free to resign from being an employee/owner. The reason an individual or primary firm remains in the network is because it provides data processing efficiencies that reduce transaction costs and other benefits. For individuals the benefits include privately funded social security, job security, vocational education, and preferred access to retail and other services. This explains the bargaining power of the industrial cooperatives to attract employee/owners and so answer the first question raised by Zingales as to "how an organization succeeds in acquiring power".

The bargaining power for Groups to attract member firms are that they provide the benefits of shared labour management, marketing, accounting and R\&D facilities with access to concessional finance which rarely requires a firm to be wound up even in difficult times. The MCC provides a case study for Zingales (2000) to "have a new theory of the costs of financial distress and consequently a new capital structure theory".

The relationships described above answers the third question raised by Zingales (2000) who said, "The third fundamental question a theory of the firm should address is how this authoritybased system operates in a way different from ordinary market contracting." In short, transactions within and between units of the MCC are governed by neither markets nor hierarchy, but by community, associative and/or network relationships. How these governance mechanisms operate "in a way different to ordinary market contracting", as sought by Zingales is explained by Hollingsworth (2000: 610-612). Coordination is achieved through "spontaneous solidarity" and "Inter- and intra-organizational concertation". The "authoritybased system" assumed by Coase (1937) and Zingales (2000) is not relevant. Coordination is achieved not through markets or commands but through shared goals and interests when there exists what Zingales describes as "the de-integration of the firm" or what Mathews describes as "network" firms.

The network, associative and community relationships of the MCC can also provide an answer to the second question posed by Zingales. He stated "The second question a theory of the firm should address is how this power is maintained and enhanced, and how it is lost". Maintaining and enhancing the network, associative and community relationships to provide greater benefits for individuals and/or firms to remain in the MCC provides an answer to this question. The alternative is for individuals and firms to accept transactions governed more by impersonal markets and alienating hierarchy. TBA provides a framework for identifying how and why transactions governed by communities, associations and networks provide data efficiencies and effectiveness as outlined in Turnbull (2000c: 245).

The complexity of the MCC nested networks is resolved and explained by TBA, which reveals that every firm and group within the whole MCC represents a holarchy of holons that share a common architecture replicated both vertically and laterally (Turnbull 2000c: 221).

Mathews (1996a: 41-44) describes holonic organisations as possessing the following characteristics: Centralisation/decentralisation; Bottom-up/top-down; Autonomous/integrated; Order/ambiguity. In comparing them with hierarchies, holonic organisations provide centralisation and decentralisation of control; systemic reliability and flexibility; systemic responsiveness; systemic learning and organisational innovations: autopoiesis. Mathews (1996a: 41) claims that: "holonic systems exhibit superior performance on all these points than conventionally structured hierarchical organisations". But it is their prodigious "reduction in data transmission and in data complexity", noted by Mathews (1996a: 30) which is of special interest as this as this reinforces the utility of TBA to explain their "superior 
performance". This has been confirmed by a World Bank study by Thomas and Logan (1982: 109) who reported that MCC "cooperatives have been more profitable than capitalist enterprises" and are "more efficient". TBA provides a new technique for empirical evaluate firms as electronic devices routinely identify the bytes transmitted or stored.

A prodigious reduction in data provides a basis for achieving a corresponding prodigious reduction in 'bounded rationality'. In firms, this provides competitive advantages in both controlling internal operations more effectively and adjusting to complex operating variables in their market place. In supporting the case for holistic systems, Beer (1987: 4) observed that, "Centralized systems don’t work and decentralized systems don't work". One of the reasons for "the failure of internal control systems" that was noted by Jensen (1993: 831) was excessive regulation as described by Bhide (1994). Firms with holonic architecture create self-regulatory components that require minimal monitoring and control to become in the words of Simon (1962) "sub assemblies", "stable intermediate forms" or "nearly decomposable systems, in which the interactions among the sub-systems are weak, but not negligible". Beer (1985: 117) refers to holons as a "viable system" and describes a number of their attributes. Hock (1994) invented the word "Chaord" to describe the holonic organisational structure of VISA International Inc, which he founded as its CEO. Hock (1994: 9)) explained that VISA International "has multiple boards of directors within a single legal entity, none of which can be considered superior or inferior, as each has irrevocable authority and autonomy over geographic or functional area".

According to Zingales (2000) "The fourth and final question a theory of the firm should address is how the surplus generated by the firm is allocated among its members". An answer to this question is provided by the MCC were internal transactions are governed by network and associative relationships rather than by markets and hierarchy. The "power coalitions" (Dallas 1988: 90) created through the network of relationships and interdependencies determine the allocation. Dallas (1988: 97) describes TCE as the "efficiency model" and states that: "the power model rejects the evolutionary or natural selection perspective of the efficiency model. The corporation is part of and, in part, creates a socially constructed reality", quoting the work of Pfeffer (1982).

TBA also provides a framework for establishing criteria for designing self-regulating components of firms and self-governing social systems (Turnbull 2000c: 118, 276/7) by applying the principles of control and communication science used to design self-regulating and self-governing machinery and devices. The use of self-regulating and self-governing components is an essential feature for managing complexity in nature and machines.

Another contribution of TBA is to relate the strategies evolved in nature to create the most efficient physical structures to the design of the most efficient social organisations. Efficiency in physical structures being the ability to maximise strength for a minimum weight such as found in the structure of cells, the human body and geodesic domes (Ingber 1998). Efficiency in social organisations and firms is the ability to establish self-governing components with the minimum transaction of bytes. In physical structures, efficiency is achieved by a strategy described as "tensegrity" achieved by using materials with opposite characteristics (Ingber 1998). In social organisation tensegrity is achieved by designing their architecture to utilise opposite human characteristics such as being competitive $\sim$ cooperative, suspicious $\sim$ trusting, self-interest altruistic, etc. For these contrary properties to emerge in social structures, compound boards are required to create interdependencies. Interdependencies provide a rational basis for trust, cooperation and altruism to emerge while also accepting suspicion, competition and self-interest between the various centres of power. In this way both agency theory (Jensen 
and Meckling 1976) and stewardship theory (Donaldson and Davis 1994) can be accepted together.

The complexity of firms having a number of control centres of boards is typically considered by many casual and serious investigators to be unnecessarily complicated and unlikely to be efficient. It is significant that even in cultures where unitary boards are believed to be the dominant form, any sustainable non-trivial employee controlled firms possess internal compound boards (Turnbull 2000b). The compounded complexity of the MCC laterally and vertically nested compound boards presents a daunting challenge to any of the established theories of the firm to explicate.

The ability of TBA to provide a framework to codify and explain this complexity in terms of structures found in nature provides a compelling reason for developing the framework as "normal science" (Kuhn 1970: 10). It provides a way of making the theory of firms a special case of a theory of organisations as sought by Jensen (1993). Because it is grounded in the natural sciences it provides a way to ground elements of social science in the natural sciences to provide a basis for developing "a science of organisation" as envisaged by some scholars (Barnard 1938: 290) and Williamson (1991: 12). TBA makes such science subject to empirical testing.

\section{References}

Alchian, A. 1950. Uncertainty, evolution, and economic theory. Journal of Political Economy 53(3): 211-211. reproduced by eds J.B. Barney and W.G. Ouchi, 1986, 305-19.

Alchian, A., and H. Demsetz. 1972. Production, information costs, and economic organization. American Economic Review 62: 777-95. reproduced by eds J.B Barney and W.G. Ouchi, 129-55, 1986.

Analytica. 1992. Board directors and corporate governance: trends in the G7 countries over the next ten years. England: Oxford Analytica Ltd.

Aoki, M. 1998. An information theoretic approach to comparative corporate governance. In Paper presented to a conference on "corporate governance". Spain: Sitgas. October 23-4. Revised November 6, 1998.

Ashby, W.R. 1960. Design for the brain: the origin of adaptive behaviour, 2nd ed. London: Chapman and Hall.

Ashby, W.R. 1968. An introduction to cybernetics. London: University Paperback.

Barnard, C. 1938. The functions of the executive. Cambridge: Harvard University Press.

Barney, J.B., and W.G. Ouchi (eds.). 1986. Organisational economics: toward a new paradigm for understanding and studying organizations. San Francisco: Jossey-Bass.

Beer, S. 1959. Cybernetics and management. London: English University Press.

Beer, S. 1966. The aborting corporate plan: a cybernetic account of the interface between planning and action. In Perspectives in planning, ed. E. Jatsch, 397-422. Paris: E. OECD.

Beer, S. 1985. Diagnosing the system for organizations. Chichester: John Wiley and Sons.

Beer, S. 1987. Holism and the Frou-Frou Solander. Opening address by the president, seventh triennial international congress of the world organization of general systems and cybernetics. London: Imperial College of Science and Technology.

Beer, S. 1995a. Brain of the firm, 2nd ed. Chichester: John Wiley and Sons.

Beer, S. 1995b. Decision and control: the meaning of operational research and management cybernetics. Chichester: John Wiley and Sons.

Beer, S. 1995c. The heart of the enterprise. Chichester: John Wiley and Sons.

Ben-Porath, Y. 1980. The F-connection: families, friend, and firms and the organization of exchange. Population and Development Review 6: 1.

Berle, A.A., and Means, G.C. 1932. The modern corporation and private property. New York: Macmillan.

Bernstein, P. 1980. Workplace democratization: its internal dynamics. New Brunswick: Transaction Books.

Bhide, A. 1994. Deficient governance. Harvard Business Review 129-139.

Blair, M.M. 1995. Ownership and control. Washington, DC: The Brookings Institution.

Blasi, J.R., and J. Gasaway. 1993. Corporate governance and employee ownership: Comparing the United States and Russia. In Paper presented to Fifth Annual Conference of the Society for the Advancement of Socio- 
Economics, March 28th. New School for Social Research, New York, Institute for Management and Labour Relations, Rutgers University.

Bruyn, S.T. 1991. A future for the American economy: the social market. Palo Alto: Stanford University Press. Coase, R.H. 1937. The nature of the firm. Economica 4: 386-405. reproduced by eds J.B. Barney and W.G. Ouchi, 1986, 80-98.

Coase, R.H. 1991a. Contracts and the activities of firms. Journal of Law and Economics 34: 451-2.

Coase, R.H. 1991b. The nature of the firm: meaning. In The nature of the firm: origins, evolution and development, ed. O.E. Williamson and S.G. Winter, 48-60. New York: Oxford University Press.

Cochrane, P. 1997. Private e-mail communication to the author dated December 21 from Peter Cochrane. UK: Head of Research, British Telecom. http://www.labs.bt.com/people.cochrap/.

Cochrane, P. 2000. Hard drive: bandwidth and brandwidth. London: Telegraph. http://www.telegraph.co. uk:80/et?ac=002781235701807andrtmo=wA0eAK5bandatmo=99999999andpg=/et/00/4/6/ecrhard06. html.

Commons, J.R. 1934. Institutional economics. Madison: University of Wisconsin Press.

Craven, D.W., N.F. Piercy, and S.H. Shipp. 1996. New organizational forms for competing in highly dynamic environments: the network paradigm. British Journal of Management 7: 203-18.

Daft, R.L., and R.H. Lengel. 1984. Information richness: a new approach to managerial behaviour and organization design. Research in Organizational Behaviour 6: 191-233.

Dallas, L.L. 1988. Two models of corporate governance: beyond Berle and Means. Journal of Law Reform. University of Michigan, Fall 22(1):19-116.

De Vany, A. 1998. How much information is there in an economic organization and why can't large ones be optimal? Brazilian Electronic Journal of Economics. http://www.beje.decon.ufpe.br/vany/information.htm.

Demb, A., and F.F. Neubauer. 1992. The corporate board: confronting the paradoxes. Oxford: Oxford University Press.

Demsetz, H. 1991. The theory of the firm revisited. In The nature of the firm: origins, evolution and development, ed. O.E. Williamson and S.G. Winter. New York: Oxford University Press.

Diermeier, D., and R.B. Myerson. 1999. Bicameralism and its consequences for the internal organisation of legislatures. The American Economic Review 89(5): 1182-1196.

Donaldson, L., and J.H. Davis. 1994. Boards and company performance - research challenges the conventional wisdom. Corporate Governance: An International Review 2(3): 151-160.

Downs, A. 1967. Inside bureaucracy. Boston: Little Brown and Co.

Dunbar, R.I.M. 1993. Coevolution of neocortical size, group size and language in humans. Behavioral and Brain Sciences 16: 681-735.

Egelhoff, W.G. 1982. Strategy and structure in multinational corporations: an informational processing approach. Administrative Science Quarterly 27: 435-458.

Etzioni, A. 1965. Organizational control structure. In Handbook of organizations, ed. J.G. March, 650-677. Chicago: Rand-McNally.

Franks, J., and C. Mayer 1993. Corporate control: a synthesis of the international evidence. In Presented to Columbia University Law School's Centre for Law and Economic Studies. New York Hilton: Conference on relationship investing: possibilities, patterns and problems.

Fukao, M. 1995. Financial integration, corporate governance and the performance of multinational companies. Washington: The Brookings Institution.

Galbraith, J.R. 1973. Designing complex organizations. MA: Addison-Wesley.

Ghoshal, S., and P. Moran. 1996. Bad for practice: a critique of the transaction cost theory. Academy of Management Review 21(1): 13-47.

Gilson, R.J., and M.J. Roe. 1993. Understanding the Japanese keiretsu: overlaps between corporate governance and industrial organization. The Yale Law Journal 102: 871-906.

Gore, A. 1996. The technology challenge: what is the role of science in American society? In Prepared remarks delivered to American Association for the Advancement of Science. Baltimore, Office of the Vice President, Washington, DC.

Hayek, F. 1945. The use of knowledge in society. American Economic Review 35: 519-530.

Hock, D.W. 1994. Institutions in the age of mindcrafting, Bionomics Annual Conference, October 22, San Francisco, California, http://ntl.bts.gov/lib/jpodocs/repts_te/259.pdf.

Hollingsworth, J.R. 2000. Doing institutional analysis for the study of innovations. Review of International Political Economy 7(4 Winter): 595-644.

Hollingsworth, J.R., and R. Boyer (eds.). 1997. Contemporary capitalism: the embeddedness of institutions. England: Cambridge University Press.

Hollingsworth, J.R., and L.N. Lindberg. 1985. The governance of the American economy: the role of markets, clans, hierarchies and associative behaviour. In Private interest government: beyond market and state, ed. W. Streeck and P.C. Schmitter, 221-67. London: Sage. 
Hollingsworth, J.R., P.C. Schmitter, and W. Streeck. 1994. Capitalism, sectors, institutions, and performance. In Governing capitalist economies, ed. J.R. Hollingsworth, P.C. Schmitter, and W. Streeck, 3-16. New York: Oxford University Press.

Ingber, D.E. 1998. The architecture of life. Scientific American 30-39.

Jackson, G. 1996. Corporate governance in comparative perspective: the interplay of networks and institutions in Germany, Japan and the United States. In Paper presented to the Eighth Conference of the Society for the Advancement for Socio-Economics, Geneva, July 14th. Cologne: Columbia University, New York and MaxPlanck-Institut for the Study of Societies.

Jensen, M.C. 1993. The modern industrial revolution: exit and the failure of internal control systems. The Journal of Finance 48(3): 831-80.

Jensen, M.C. 2000. Value maximization, stakeholder theory, and the corporate objective function. In Breaking the Code of Change, eds. Beer, M., and N. Norhia. Harvard Business School Press. http://papers.ssrn.com/paper. taf?abstract_id=220671.

Jensen, M.C., and W.H. Meckling. 1976. Theory of the firm: managerial behaviour, agency costs and ownership structure. Journal of Financial Economics 3: 305-60.

Kester, W.C. 1992. Industrial groups as system of contractual governance. Oxford Review of Economics Policy 8: 3.

Klaes, M. 2000. The birth of the concept of transaction costs: issues and controversies. Industrial and Corporate Change 9(4): 567-93.

Koestler, C.O. 1967. The ghost in the machine. London: Hutchinson.

Kuhn, T.S. 1970. The structure of scientific revolutions, 2nd ed. USA: The University of Chicago Press.

Kurzweil, R. 1999. The age of spiritual machines: when computers exceed human intelligence. New York: Viking.

Mathews, J. 1996a. Holonic organisational architectures. Human Systems Management 15: 27-54.

Mathews, J. 1996b. Organizational foundations of economic learning. Human Systems Management 15: 113-24.

MCC. 2015. Annual report. Spain: Mondragón Corporación Cooperativa, Mondragón.

Molho, I. 1997. The economics of information: lying and cheating in markets and organizations. Oxford: Blackwell.

Nahapiet, J., and S. Ghoshal. 1998. Social capital, intellectual capital and the organizational advantage. The Academy of Management Review 23(2): 242-266.

Newton's. 2001. Newton's telecom dictionary. New York: CMP Books.

Nohira, N., and R.G. Eccles. 1992. Networks and organizations: structure, form and action. Cambridge: Harvard University.

North, D.C. 1985. Transaction costs in history. Journal of European Economic History 4: 557-72.

Ouchi, W.G. 1980. Markets, bureaucracies and clans. Administrative Science Quarterly 25: 124-141.

Ouchi, W.G. 1984. The M-form society. MA: Addison Wesley.

Oxford 1956. Shorter Oxford English Dictionary, Revised and edited by C. T. Onions, Third edition revised with addenda, Oxford.

Pejovich, S. 1990. The economics of property rights: towards a theory of comparative systems. Netherlands: Kluwer.

Persson, T., Roland, G., and Tabellini, G. 1996. Separation of powers and accountability: Towards a formal approach to comparative politics. Innocenzo Gasparini Institute for Economic Research (IGIER), Working Paper, No. 100, July, Milan.

Pfeffer, J. 1982. Organizations and organization theories. Boston: Pitman.

Pirson, M., and S. Turnbull. 2011. Towards more humanistic governance: network governance structures. The Journal of Business Ethics 99(1): 101-114. http://www.springerlink.com/content/k26 w255266718176/fulltext.pdf.

Podolny, J.M., and K.L. Page. 1997. Network forms of organization, Working paper, Graduate School of Business. Stanford University. http://papers.ssrn.com/.

Porta, R.L., R.F. Lopez-de-Silanes, and A. Schleifer. 1999. Corporate ownership around the world. Journal of Finance 54: 471-517.

Porter, M.E. 1992. Capital choices: changing the way America invests in industry. A research report presented to the Council on Competitiveness and co-sponsored by The Harvard Business School, Boston.

Princeton. 2000. Princeton alumni weekly obituary. USA: Princeton University. http://libweb.princeton.edu:2003 /libraries/firestone/rbsc/finding_aids/mathoral/pmcxtukey.htm\#paw.

Radner, R. 1992. Hierarchy: the economics of managing. Journal of Economic Literature 30: 1282-415.

Radner, R. 2000. Costly and bounded rationality in individual and team decision-making. Industrial and Corporate Change 9(4): 623-58.

Shannon, C.E. 1949. The mathematical theory of communications, 1-94. Urbana: The University of Illinois Press. 
Shleifer, A., and R.W. Vishny. 1996. A survey of corporate governance. Cambridge: National Bureau of Economic Research. Working paper 5554.

Simon, H.A. 1957. Models of man. NY: John Wiley and Sons.

Simon, H. 1962. The architecture of complexity. Proceedings of the American Philosophical Society 106: 46782.

Simon, H. 1984. On the behavioral and rational foundations of economic dynamics. Journal of Economic Behavior and Oganization 5: 35-56.

Smith, C.W. 2001. Organizational architecture and corporate finance. The Journal of Financial Research XXIV(1): 1-13. Spring.

Sternberg, E. 1996. Stakeholder theory exposed. In Corporate governance quarterly. Hong Kong Institute of Company Secretaries 2(1):4-18.

Tannenbaum, A.S. 1962. Control in organizations. NY: McGraw-Hill.

Thomas, H., and C. Logan. 1982. Mondragón: an economic analysis. London: George Allen and Unwin.

Turnbull, S. 1993. Flaws and remedies in corporatisation and privatisation. Human Systems Management 12(3): 227-52.

Turnbull, S. 1995a. Best practice in the governance of GBEs. In The Australian public sector: pathways to change in the 1990s, ed. J. Guthrie, 99-109. Sydney: IIR Pty. Limited.

Turnbull, S. 1995b. Corporate governance: what is world best practice. In Australian Company Secretary. Sydney: Chartered Institute of Company Secretaries in Australia Limited, pp 485-91.

Turnbull, S. 1995c. Innovations in corporate governance: the Mondragón experience. Corporate Governance: An International Review 3(3): 167-80. http://cog.kent.edu/lib/Turnbull6.htm.

Turnbull, S. 1997a. Corporate governance reform: improving competitiveness and self-regulation. In Paper presented to Corporate Law Economic Reform Program Conference. Canberra: Australian National University. http://papers.ssrn.com/paper.taf?ABSTRACT_ID=41383.

Turnbull, S. 1997b. Stakeholder governance: a cybernetic and property rights analysis. Corporate Governance: An International Review 5(1)11-23. http://cog.kent.edu/lib/turnbull6/turnbull6.html, reprinted in Corporate Governance: The history of management thought, R.I Tricker, ed, Ashgate Publishing, pp. 401-13, 2000, London.

Turnbull, S. 1997c. The application of cybernetic knowledge in governing society. In International conference on Knowledge, Economy and Society. Québec: University of Montréal.

Turnbull, S. 2000a. Corporate charters with competitive advantages. NY: St. John's Law Review, 89:77-174. http://papers.ssrn.com/sol3/paper.taf?ABSTRACT_ID=10570. Full text without figures from Lexis/Nexis http://www.lexis-nexis.com/lncc/ and Westlaw http://www.westlaw.com/.

Turnbull, S. 2000b. Employee governance. In Paper presented to The First European Conference on Corporate Governance, November 16th, Brussels, Belguim. http://papers.ssrn.com/sol3/papers.cfm?cfid=196284 andcftoken=90592070andabstract_id=253349.

Turnbull, S. 2000c. The governance of firms controlled by more than one board: Theory development and examples. PhD dissertation, Macquarie University, Sydney, Australia, 2000. http://ssrn. com/abstract $=858244$.

Turnbull, S. 2000d. Why unitary boards are not best practice: the case for compound boards. In Paper presented to The First European Conference on Corporate Governance, November 16th, Brussels, Belguim. http://papers.ssrn.com/sol3/papers.cfm?cfid=196284andcftoken=90592070andabstract id=253803.

Turnbull, S. 2001. The competitive advantage of stakeholder mutuals. In The New Mutualism, ed. Birchall, J., Chapter 9, pp. 171-201. London: Routledge. http://ssrn.com/abstract=242779.

Turnbull, S. 2002a. A new way to govern: organizations and society after enron. London: New Economics Foundation. http://ssrn.com/abstract_id=319867.

Turnbull, S. 2002b. The science of corporate governance. Corporate Governance: An International Review 10(4): 256-272. http://ssrn.com/abstract_id=316939.

Turnbull, S. 2007. Analysing network governance of public assets. Corporate Governance: An International Review 15(6): 1079-1089. http://papers.ssrn.com/abstract_id=786805.

Turnbull, S. 2008. The science of governance: a blind spot of risk managers and corporate governance reform. Journal of Risk Management in Financial Institutions 1(4): 360-368. http://ssrn.com/abstract=1742584.

Turnbull, S. 2014a. How might network governance found in nature protect nature? Journal of European Law 11(2): 98-102. https://www.kluwerlawonline.com/document.php?id=EUCL2014019.

Turnbull, S. 2014b. Practices, science and art of drafting corporate charters and Bylaws. Video to introduce assigned reading. A new way to govern: organisations and society after enron. In course presented by the Swiss International Law School. available: at: https://vimeo.com/138517623. Accessed code: SiLS.

Turnbull, S., and M. Pirson. 2015. The future of corporate governance: network governance - a lesson from the financial crisis. Human Systems Management 34: 81-89. http://ssrn.com/abstract=1570924. 
Turnbull, S. 2016. Defining and achieving good governance. In Corporate behaviour and sustainability: doing well by being good, eds. Güler Aras and Coral Ingley, Chapter 13, pp. 232-249. UK: Ashgate Publishing Ltd. Working paper: http://ssrn.com/abstract=2571724.

Van Alstyne, M. 1997. The state of network organization: a survey in three frameworks. Journal of Organizational Computing 7: 3. http://mitsloan.mit.edu/.

Van Zandt, T. 2000. Decentralized informational processing in the theory of organizations. In Contemporary economic issues, 4, economic design and behavior, ed. Murat Sertel, Chapter 7, pp. 125-160. London: MacMillan Press Ltd. http://zandtwerk.insead.fr/org-papers.html\#S3.

von Neumann, J. 1947. Theory of games and economic behaviour. CT: Yale Univerity Press.

Wearing, A.J. 1973. Economic growth: magnificent obsession. In Paper presented to 44th Australian and New Zealand Association for the Advancement of Science Congress, August, Perth, Australia.

Wiener, N. 1948. Cybernetics. NY: John Wiley and Sons.

Williamson, O.E. 1975. Markets and hierarchies: analysis and anti-trust implications. NY: Free Press.

Williamson, O.E. 1979. Transaction cost economics: the governance of transactional relations. Journal of Law and Economics 22: 233-61. reproduced by eds J.B. Barney and W.G. Ouchi, 1986, 98-129.

Williamson, O.E. 1985. The economic institutions of capitalism. NY: Free Press.

Williamson, O.E. 1988. The logic of economic organization. Journal of Law Economics and Organization 4(1): 65-93.

Williamson, O.E. 1990. Industrial organisation. London: Gower House.

Williamson, O.E. 1991. Introduction. In The nature of the firm: origins, evolution and development, ed. O.E. Williamson and S.G. Winter, 1-17. NY: Oxford University Press.

Winter, S.G. 1991. On coase competence and the corporation. In The nature of the firm: origins, evolution and development, ed. O.E. Williamson and S.G. Winter, 179-195. NY: Oxford University Press.

Zey, M., and T. Swenson. 2001. The transformation and survival of Fortune 500 industrial corporations through mergers and acquisitions, 1981-1995. The Sociological Quarterly 42(3): 461-486. https://www.academia. edu/14747756/THE_TRANSFORMATION_AND_SURVIVAL_OF_FORTUNE_500_INDUSTRIAL_ CORPORATIONS_THROUGH_MERGERS_AND_ACQUISITIONNS_1981-1995.

Zingales, L. 2000. In search of new foundations. The Journal of Finance 55(4): 1623-1653. 